\title{
Company Size, Profitability and Leverage to Tax Agresifity (Empirical Study to Manufacturing Subsector Paper, Advertising, Printing, Media in Indonesian Stock Exchange (BEI) Tahun 2015 - 2018)
}

\author{
Feber Sormin. \\ Universitas Mercu Buana, Jakarta Indonesia
}

\begin{abstract}
This study analyzes the effect of company size, profitability and leverage on tax aggressiveness measures in the manufacturing companies in the paper and advertising, printing and recording media industries listed on the Jakarta Stock Exchange. Data Population observations for the period 2015 to 2018 and obtained sample 46 with the Saturation Point Sample. The data analysis method used in the study is multiple regression analysis with SPSS statistical tools. The t-test results concluded that company size and profitability had a positive effect on tax aggressiveness. Leverage does not affect tax aggressive actions, while the F-test concluded that company size, profitability ratio (ROA) and leverage (DER) together affect tax aggressiveness.
\end{abstract}

Keywords: company size (total sales), profitability (ROA), leverage (DER) and tax aggressiveness.

DOI: $10.7176 / \mathrm{EJBM} / 12-18-04$

Publication date:June 30th 2020

\section{INTRODUCTION}

In modern era, Tax Revenue is one of the cash revenue in countries. The state revenue from the tax sector plays a very important role for the continuity of the government system. As the role of Tax which is the rights and obligations to the state owed by individuals or entities by not getting a direct reward and used for the needs of the country for the prosperity of the people. From the definition of tax based on Indonesian Law, it means that every taxpayer has mandatory contribution to a compulsive state by not getting a direct reward, so based on the regulation, the government sets a tax revenue target that must be collected from existing taxpayers. Based on the revenue target achieved from 2015 to 2018, it can be said that it has not reached the target based on the state budget, including the level of tax compliance based on the number of registered taxpayers who have not reached the target either from individual taxpayers or from corporate taxpayers.

Experts and officials believe that there are many factors why the tax compliance target and level up to now has not reached expectations, one of which is tax evasion carried out by taxpayers through tax management, which certainly can affect the achievement of state revenues as expected. The actions of taxpayers can be categorized as tax refusal through actions to practice tax avoidance through tax management. Management who works for the owner, of course, makes every effort to give more benefits to the owner / investor as a form of loyalty compared to paying taxes to the state. Not infrequently we find cases arising from the treatment of tax management that is not according to the rules.

Chairil Anwar Pohan (2015: 5) states "Tax planning is a tool and an initial stage of tax management that functions to accommodate the aspirations that develop from human nature. Tax Management has a wider scope than just tax planning. As a tax management, surely it is inseparable from the general management concept which is a systematic effort which includes Planning, Organizing, Actuating, and Controlling". Based on this explanation, the researcher can conclude that tax planning is a part of more specific tax management, which in tax planning there is a classification namely Tax Avoidance that does not violate regulations (Tax Avoidance) and Tax Avoidance that violates tax regulations ( Tax Avasion) and tax savings (tax saaving) with the aim of getting more benefits than they should. Sometimes, tax avoidance or tax non-compliance has reacted by investors and tax compliance has not (Tarmidi, 2019). Avoiding taxpayers to reduce their tax payments is mostly done in various ways to avoid taxation (tax avoidance). Giawan Nur Fitria (2018 stated that company size influences tax avoidance. Generally, the bigger the company, the more company assets and certainly makes the operational costs borne by the company bigger and complex, especially how to reduce the burdens, including tax aggressiveness, both tax avoidance and tax avasion."Indonesian Finance Minister Sri Mulyani Indrawati conveyed the realization of state revenues which reached Rp1,957.2 trillion (90.4\% of the 2019 APBN target) at the 2019 APBN Report press conference. When compared to 2018 achievements, 2019 realization of state revenues It grew $0.7 \%$. More specifically, the realization of the country's revenue consisted of tax revenue of Rp1,545.3 trillion (86.5\% of the 2019 APBN target), State RevenueNon-Tax (PNBP) of IDR 405 trillion (107.1\% of the 2019 APBN target) and grants of IDR 6.8 trillion ... "."The act of tax aggressiveness or also called aggressive tax is an action that aims to reduce taxable profits through tax planning using either tax avoidance or illegally by tax evasion or by making tax savings (tax evasion) tax saving). Aggressive taxation can also be judged by how much the company takes tax 
avoidance steps by exploiting the gaps in tax regulations. Therefore, the company will be considered more aggressive. " (Thomas Sumarsan, 2013: 8).

Based on tax cases, it can be seen that there are still many companies that are aggressive in avoiding or reducing the payment of tax obligations according to the existing rules. Seen various efforts made by management to avoid taxes. For the government, taxes paid by companies are one of the main sources of income. Conversely, for companies as corporate taxpayers, taxes are costs that will reduce revenue. This difference causes the objectives of companies as taxpayers to conflict with the government's goal of maximizing revenue from the tax sector. Various company management efforts are specifically designed to aggressively minimize tax burdens. Tax aggressiveness can be defined as all efforts made by management to reduce the amount of tax burden than should be paid by the company (Lanis and Richardson, 2012).

Based on previous research there are several variables that influence tax aggressive actions, these variables include: profitability, Corporate Social Responsibility (CSR), Good Corporate governance (GCG), leverage, family ownership, liquidity, characteristics of company ownership, company size, inventory intensity, capital intensity, executive character and also several other factor variables. Among several factors that influence the existence of tax aggressiveness, the researcher uses the size of the company that is projected in this study are Total Sales, profitability proxied by ROA and leverage ratio proxied by DER.

The definition of company size is based on Bambang Riyanto (2001: 299), "Firm size is a description of the size of a company shown in total assets, total sales, average sales and total assets." Bringham and Houston (2006: 25) explain that company size is the average of total net sales for the year up to several years. In this case the sale is greater than the variable costs and fixed costs, then the amount of income before tax will be obtained. Conversely, if sales are smaller than variable costs and fixed costs the company will suffer losses.

Previous research A.W Laksono; S.S Albertus; R.Vhalery (2019) said company size, profitability had a negative effect on tax aggressiveness, and together company size and profitability affected tax aggressiveness. In Findria P's research (2017) mentioned, Company Size has no effect on tax aggressiveness. Dewi Nawang Gemilang (2017), said that company size has no significant effect on corporate tax aggressiveness.

Another factor causing tax aggressive action is profitability, according to G. Sugiyarso and F. Winarni (2005: 118) Profitability is the ability of companies to make profits in relation to the sale of total assets and own capital. From this definition it is clear that the target to be sought is the company's profit. Profitability of a company shows the ratio between earnings with assets or capital that generates profits. In other words, profitability is the ability of a company to achieve profits. Company profitability is one of the bases for evaluating the condition of a company. Profitability is a value or benchmark that is often seen by investors to assess company performance. Profitability research used in this study is proxied to the Return on Assets (ROA) ratio. In the analysis of financial statements, the value of profitability is the most highlighted, because it is able to show the company's success in making profits. Return on Assets (ROA) is able to measure the company's ability to generate profits in the past and then projected in the future.

Putu Ayu Seri Andhari and I Made Sukartha (2017), stated that profitability has a positive effect on tax aggressiveness the more a company earns profits, the more aggressively the company conducts grinding practices. ts tax obligations. Agus Taupik Hidayat1, Eta Febrina Fitria2 (2018), Profitability research does not affect tax aggressiveness, companies, the same as Adeherdian Permata Putri research results (2019), Return on Assets (ROA) has no significant effect on tax aggressiveness.

Another factor that influences tax aggressiveness is leverage ratio. Leverage Ratio or Solvency Ratio is the use of assets and sources of funds by companies that have fixed costs (fixed costs) with a view to increasing the profitability of potential shareholders (Sartono, 2008: 257). Leverage is a level of a company's ability to use assets and / or funds that have a fixed burden (debt and or special stock) in order to realize the company's goals to maximize the owner's wealth. According to Yulfaida (2012) leverage is the amount of debt a company has for financing and can measure the amount of assets financed by debt. Companies with high leverage indicate the company is dependent on external loans or debt, while companies with low leverage can finance their assets with their own capital. The size of the leverage on the company can affect the size of the tax paid by the company. This is because the interest costs from debt can be deducted in calculating taxes so that the tax burden becomes smaller. The above situation is in accordance with the research of Richardson and Lanis (2007) and Noor (2010) which states that interest costs can reduce the amount of tax burden, so the higher the level of leverage will cause the Effective Tax Rate (ETR) to be smaller.

Leverage Ratio or Solvabilits ratio in this study uses Debt to Equity Ratio (DER), considering that the greater the debt owned by the company will have an impact the greater the interest borne by the entity, and this will have an impact on the tax burden to be borne. Imam Fadli's research (2016) states that leverage influences corporate tax aggressiveness. In Andy's Research (2018), The Effect of Return on Assets, Debt to Equity Ratio, EBT to Asset Ratio, Company Size and Derred Tax Expense on Tax Avoidance, Partially Return on Assets, Debt to Equity Ratio (DER) and Debt to Asest Ratio (DAR) has no significant effect on tax avoidance, while simultaneous Return on Assets, Debt to Equity Ratio (DER) and Debt to Asest Ratio (DAR) have a significant effect on tax avoidance. 
While the results of previous studies by Dewi Nawang Gemilang (2017) examined the effect of liquidity, leverage, profitability of company size, and capital intensity on corporate tax aggressiveness. shows that profitability has a significant effect on corporate tax aggressiveness. While liquidity, leverage, company size and capital intensity do not have a significant effect on corporate tax aggressiveness., with the formulation of the problem in this study as follows:

1. Does company size influence tax aggressiveness?

2. Does profitability proxied by Return on Asset Ratio (DAR) affect tax Aggressiveness?

3. Does the leverage proxied by Debt to Equity Ratio (DER) affect the tax aggressiveness?

\section{THEORITICAL FRAMEWORK}

1. Effect of Company Size on Tax Aggressiveness.

The definition of company size is based on Bambang Riyanto (2001: 299), "Firm size is a description of the size of a company shown in total assets, total sales, average sales and total assets." Bringham and Houston (2006: 25) explain that company size is "The average total net sales for the year in question for several years. In this case the sale is greater than the variable costs and fixed costs, then the amount of income before tax will be obtained. Conversely, if sales are smaller than variable costs and fixed costs the company will suffer losses. " The larger size of the company certainly has more complex management behavior in managing the company's operations. Largescale companies certainly have more experience to carry out their operations, and have more experience in strategies for operational sustainability, including tax minimization (Kristanto, 2013). The size of the company in this study, will proxy total sales, because it makes it easier to get research data taken from financial reports according to the year under study.

In A.W Laksono's research; S.S Albertus; R.halhal (2019) mentions company size, profitability, which has a negative effect on tax aggressiveness and simultaneously company size and profitability, which has an effect on tax aggressiveness. Vita Avianti Lusiana (2017 mentions that company size has a negative and not significant effect on tax aggressiveness, Findria P Research (2017) says, company size has no effect on tax aggressiveness. Dewi Nawang Gemilang (2017), says that company size has no significant effect on corporate tax aggressiveness. 2. Effect of Profitability on Tax Aggressiveness.

According to G. Sugiyarso and F. Winarni (2005: 118) profitability is the ability of companies to earn profits in relation to the sale of total assets and own capital. Profitability of a company shows the ratio between earnings with assets or capital that generates profits. Profitability is a value or benchmark that is often seen by investors to assess company performance. The profitability calculation used in this is Return On Assets (ROA). Dendawijaya (2003: 120) states ROA illustrates the ability of management to obtain profits (profits). The higher ROA, the higher the profit of the company so that the better the management of company assets.

Putu Ayu Seri Andhari and I Made Sukartha (2017), stated that profitability has a positive effect on tax aggressiveness, the greater the company earns profits, the more aggressive the company practices avoidance of its tax obligations. Agus Taupik Hidayat1, Eta Febrina Fitria2 (2018), Profitability research does not affect tax aggressiveness, companies, the same as Adeherdian Permata Putri research results (2019), Return on Assets (ROA) has no significant effect on tax aggressiveness.

3. Effect of Leverage on Aggressive Tax Actions.

Leverage Ratio or Solvency Ratio is the use of assets and sources of funds by companies that have fixed costs (fixed costs) with a view to increasing the profitability of potential shareholders (Sartono, 2008: 257). Leverage is a level of the company's ability to use assets and or funds that have a fixed burden (debt and or special stock) in order to realize the company's goals to maximize the wealth of the owner of the company. Companies with high leverage indicate the company is dependent on external loans or debt, while companies with low leverage can finance their assets with their own capital. The size of the leverage on the company can affect the size of the tax paid by the company. This is because the interest costs from debt can be deducted in calculating taxes so that the tax burden becomes smaller. In this research the leverage ratio is proxied by Debt to Equity Ratio (DER), considering that the greater the debt owned by the company will have an impact the greater the interest borne by the entity, and this will have an impact on the tax burden to be borne.In the study of Imam Fadli (2016) states leverage affects the aggressiveness company tax. In Andy's Research (2018), mentioning Debt to Equity Ratio (DER) had no significant effect on tax avoidance, while Simultaneous Debt to Equity Ratio (DER) had a significant effect on tax avoidance.

Based on what he explained, regarding the effect of the Independent Variable on the Dependent variable, a framework for this research was formed that illustrates the relationship between the variables, shown in the figure below: 
Figure 2.1 Logical Framework

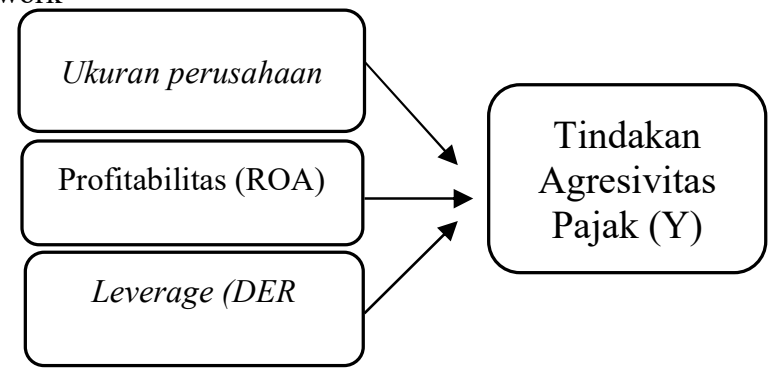

\section{HYPOTHESIS}

Based on the framework and background that have been explained by researchers, as well as Literature Review, the researchers formulated the hypothesis of this study are as follows:

$\mathrm{H} 1=$ company size is proxied by total sales effect on tax aggressiveness.

$\mathrm{H} 2$ = Profitability proxied by ROA affects the Tax Aggressiveness Actions.

H3 = Leverage which is promoted by DER has an effect on Tax Aggressiveness.

\section{RESEARCH METHOD}

The research conducted in 2020, the research location was the Indonesia Stock Exchange, which provided information on the company's financial statements by accessing the official website of the Indonesia Stock Exchange, www.idx.co.id and also from the company's publication media which became the population of the research sample. This study uses secondary data with the object of research are Company Size, Profitability, Leverage and Tax Aggressiveness Measures by taking data on financial statements of companies listed on the Indonesia Stock Exchange during 2015-2018.

The research design used in this study is causal research. Causal research is research that aims to examine the effect or relationship of one or several variables (independent variables) to other variables (dependent variable). This study aims to examine the effect of company size, profitability, leverage with tax aggressiveness measures.

A. Definition of variable Operational

The definition of research is a limitation or meaning, it can also be interpreted words, phrases, or sentences that express the meaning, description, or the main characteristics of people, objects, processes or activities. Operational variables are needed to determine the type of indicator as well as the scale of the variables related in the study, so that hypothesis testing with statistical tools can be carried out correctly in accordance with the title of the study regarding the effect of company size, profitability, and leverage against aggressive tax actions.

\section{Tax Agressiveness (Variable Y)}

Tax Aggressiveness or corporate tax aggressiveness is an action that aims to reduce taxable profits through tax planning using either tax avoidance or illegally tax evasion. (Thomas Sumarsan, 2013: 8).

This study uses the Proxy of Effective Tax Rate (ETR) in the measurement of tax aggressiveness with the consideration that the proxy is the most widely used in previous studies and to determine the existence of tax aggressiveness by looking at the value of Effective Tax Rate (ETR) is low (Lanis and Richardson, 2013) . A low Effective Tax Rate (ETR) shows that income tax burden is smaller than pre-tax income. The formula for calculating ETR is to divide the income tax expense divided by profit before tax. The dimension used to measure the Aggressiveness Act of this study uses the ETR (Effective Tax Rate) proxy, which is the income tax expense divided by profit before tax by the Ratio Scale.

$\mathrm{ETR}=$ Income Tax Expense Profit before tax

ROA $=$ Net Profit $\times 100 \%$

Total Assets

c. Leverage (X3)

Leverage is the use of assets and sources of funds by companies that have fixed costs (fixed costs) with a view to increasing potential shareholder returns (Sartono, 2008: 257). Leverage is a level of a company's ability to use assets and / or funds that have a fixed burden (debt and or special stock) in order to realize the company's goals to maximize the owner's wealth.

Dimension The leverage ratio is measured by dividing the total debt by the total assets of the company (M.hanafih \& Abdul Halim, 2014: 159). Research indicators used to measure Debt to Equity Ratio (DER) by calculating Total Debt divided by Total Capital using the Ratio scale.

DER $=$ Total Debt

Total Capital 
1. Population

The population in this study was carried out in manufacturing companies in the Paper and Advertising, Printing and Recording Media sub-sectors listed on the Indonesia Stock Exchange in 2015 up to 2018, amounting to 15 companies. The Population Criteria chosen to be sampled are:

- Manufacturing companies in the industrial sector in the Manufacturing Companies sub-sector Paper and Advertising Industry, Printing and Recording Media which are listed on the Indonesia Stock Exchange (BEI) in 2015 - 2018 (15).

- Companies that issue complete financial statements for the period 2015 - 2018 (15).

- Number of Companies that meet the criteria to become Population based on the entire financial reporting period Profit from 2015 to 2018 (8).

- Companies whose financial statements for 4 years Loss from the period between 2015 to 2018 (3).

- Number of Companies Financial statements in the last 4 years there were periods of loss and profit from / between 2015 to 2018 (4).

- Number of Company Populations that have made a profit and lost from 2015 to 2018. (12).

- Total Population will be examined 4 years from 2015 to 2018 (12 x 4) (48).

- Data outlier (2).

Number of Samples used for SPSS data processing (46).

2. Samples

Erwan A.P; Dyah R.S (2011: 37) states that Samples are part of the population chosen following certain procedures so that they can represent the population. The sampling technique used in this study is to use the Saturation Point Sample, which is a sample that uses the entire population, this is because the total population is below 100. Arikunto (2012: 104) states that if the number of samples is less than 100 people, the number of samples is taken as a whole, but if the population is greater than 100 people, then it can be taken from 10 to $15 \%$ or 20 to $25 \%$ of the total population. Based on the population of this study, because the total population is 48 data and no more than 100 data, the researchers take all the Financial Statements data of profit in each manufacturing period in the Industrial sector in the Manufacturing Companies sub-sector of the Paper and Advertising Industry, Printing and Recording Media registered in Indonesia Stock Exchange (IDX) in 2015 2018.

Data Collection Method

Data collection methods according to Erwan A.P; Dyah R.S (2011:36) can be done with experimental research techniques, survey research, content analysis and secondary data research (Existing statistics). The method used in collecting data in this study is the method of documentation from secondary data sources by collecting, recording, and ensure that the estimated model meets the regression assumptions, researchers use the classic assumption test which includes:

a. Normality test

Normality test aims to test whether in the regression model, confounding or residual variables have a normal distribution (Ghozali, 2013: 160). A good regression model is to have a normally distributed residual value. Data that is not normally distributed can be transformed to become normal. This research is planned to use the Kolmogorov-Smirnov test to test the normality of normally distributed data or not. Decision making to determine whether or not the data is normally distributed is as follows:

Asymp Value. Sig (2-tailed) $>0.05$ then it is normally distributed

Asymp Value. Sig (2-tailed) $<0.05$ then the data is not normally distributed.

Kolmogorov-Smirnov (K-S). K-S test is done by making a hypothesis:

H0: residual data are normally distributed.

HA: residual data are not normally distributed (Ghozali, 2013: 164).

b. Multiculturality Test

Multicollinearity test aims to test whether the regression model found a correlation between independent variables (independent) (Ghozali, 2013). A good regression model should not occur correlation between independent variables. To find out the correlation between variables by looking at the value of tolerance and VIF. In order to avoid correlation, the value that must be met is tolerance value $>0.10$ and VIF value $<10$. To know whether there is multicollinity in the regression model can be seen in the following way: R2 The R2 value generated by an estimation of the empirical regression model is very high, but individually many independent variables do not significantly influence the related variables.

Analyze the correlation matrix of the independent variables. If between independent variables there is a fairly high correlation (generally above 0.90 ), then this is an indication of multicollonity. Look at the value of tolerance and variance inflation factor (VIF). The value of multicollinity is a tolerance value $>0.10$ or equal to a VIF value $<10$ (Ghozali, 2013: 110).

c. Autocorrelation Test 
The autocorrelation test aims to test whether in the linear regression model there is a correlation between the error of the intruder in the $t$ period and the error of the intruder in the $t-1$ period (before) (Ghozali, 2013). Autocorrelation arises because sequential observations all the time are related to one another. This problem arises because residuals are not free from one observation to another. Some of the tests used to detect the presence or absence of autocorrelation include the Durbin-Watson test, the Lagrange Multiplier Test (LM Test), the Q Statistical Test and the Test run test (Ghozali, 2013: 110). In this study will use a run test with the criteria for determining whether autocorrelation symptoms have occurred or not, can be seen from if the Asymp value. Sig. (2-tailed) is greater than 0.05 then there are no symptoms of autocorrelation, so the autocorrelation test is fulfilled.

d. Heteroscedasticity Test

Heteroscedasticity test is used to aim to test whether in the regression model there is an inequality of variance from the residuals of one observation to another (Ghozali, 2013: 139). If the variance from one observation residual to another observation is fixed, then it is called Homoscedasticity and if different is called heteroscedasticity. One method used to detect heteroscedasticity is to see a scatterplot graph between standardized predicted value (ZPRED) and studentized risk (SRESID).

Basic decision making test for heteroscedasticity, namely: If there are certain patterns such as the points that form a certain regular pattern, then heteroscedasticity occurs. If there is no clear pattern, and the points spread above and below ang 0 on the $\mathrm{Y}$ axis, then Heteroscedasticity does not occur ..

3. Model Suitability Test

a. Determination Coefficient Test $\left(\mathrm{R}^{2}\right)$

The coefficient of determination (R2) is intended to measure the extent to which the ability of the model or independent variables together affect the variation of the dependent variable. The coefficient of determination (R2) in the regression model between 0 and 1 , where the value of R2 is small or close to 0 means the ability of independent variables in explaining the variation of the dependent variable is very limited, on the contrary, if R2 is getting closer to $100 \%$ means all the independent variables in the mold provide almost all the information needed to predict the dependent variable or the greater the influence of all the independent variables on the variabledependent, Erwian A.P; Dyah R.S (2011: 195).

b. Simultaneous Significant Test (F-Test Test)

F statistical test shows whether all independent variables included in the model have a joint influence on the dependent variable (Ghozali, 2013: 98). In the conclusion test taken is to look at the significance $(\alpha)$ with the following provisions:

1) If the significance value $F<0.05$ and $F$ arithmetic $>F$ table, it can be concluded that all independent variables simultaneously or simultaneously affect the dependent variable.

2) If a significant level of $F>0.05$ and $F$ arithmetic $<$ from $F$ table then it can be concluded that all the independent variables simultaneously or simultaneously do not affect the dependent variable.

4. Hypothesis Testing

a. Significance Test of Individual Parameters (T-Test)

Statistical test $t$ basically to find out how far the influence of one independent variable individually in explaining the variation of the dependent variable (Ghozali, 2013: 98). Returns are made based on a comparison of the $t$ value of each coefficient of $t$ regression with $t$ table in accordance with the level of significance used. Acceptance or rejection of the hypothesis is carried out with the following criteria:

1) If the significance value of $\mathrm{t}<0.05$ then $\mathrm{H} 0$ is rejected, it means that there is a significant influence between one independent variable on the dependent variable.

2) If the significance value of $\mathrm{t}>0.05$ then $\mathrm{H} 0$ is accepted, it means that there is no significant effect between one independent variable and the dependent variable.

b. Multiple Linear Regression Test

This study uses multiple regression to describe the relationship of several variables, so that a variable can be predicted from other variables. The form of the equation in this study is:

$\mathrm{Y}=\alpha+\beta 1(\mathrm{X} 1)+\beta 2(\mathrm{X} 2)+\beta 3(\mathrm{X} 3)+\mathrm{e}$

Information $: \mathrm{Y}=$ Aggressive Tax Actions

$\mathrm{a}=$ constant

$\mathrm{X} 1$ = company size $($ Size $)$

$\mathrm{X} 2$ = Profitability (ROA)

$\mathrm{X} 3=$ Leverage $(\mathrm{DER})$

$\mathrm{e}=$ error

VI. RESULTS AND DISCUSSION

VIA. RESULTS

VI.A.1 Data Analysis

VI.A.1.1 Descriptive Statistics Analysis 
Descriptive statistics provide a description or description of a data that is seen from the average value (mean), standard deviation, variance, maximum, minimum, sum, range, kurtosis and swekness (distribution victory) (Ghozali, 2013: 19). Descriptive statistical analysis in this study for recording data accompanied by figures which are values and can be given an objective picture of the variables to be examined.

Descriptive Statistics

\begin{tabular}{|l|r|r|r|r|r|r|}
\hline & \multicolumn{1}{|c|}{$\mathrm{N}$} & \multicolumn{1}{c|}{ Minimum } & \multicolumn{1}{c|}{ Maximum } & \multicolumn{1}{c|}{ Mean } & Std. Deviation & \multicolumn{1}{c|}{ Variance } \\
\hline SIZE & 46 & 16,0430 & 29,9270 & 26,784804 & 3,1233222 & 9,755 \\
ROA & 46 &, 0000 &, 3330 &, 089261 &, 0818175 &, 007 \\
DER & 46 &, 1870 & 15,6460 & 3,586500 & 3,7807461 & 14,294 \\
ETR & 46 &, 0000 &, 3510 &, 204109 &, 1141440 &, 013 \\
Valid N (listwise) & 46 & & & & & \\
\hline
\end{tabular}

1. Based on table 4.1 above, some information can be explained as follows:

2. 1. From the analysis results obtained a minimum value of 0,000 or $0 \%$ owned by Fortune Indonesia Tbk PT in 2016 which means the company has the lowest level of Tax Aggressiveness of 0\%, while the maximum value of 0.3510 is owned by Media Nusantara Citra Tbk PT in 2017 which means that it has the highest Tax Aggressiveness rate of 35.10\%. The Mean Value of Tax Aggressiveness proxied by Effective Tax Ratio (ETR) is 0.204109 owned by Media Nusantara Citra Tbk PT in 2015 which means that on average Indonesian companies have a Tax Aggressiveness rate of $20.4 \%$.

3. The company size variable, the descriptive statistical results show the drinking value of the company size of 16,040 owned by Elang Mahkota Teknologi Tbk PT in 2016 which means the company has the lowest level of company size (SIZE) of $160.40 \%$, while the maximum value of 29.9270 owned by Fajar Surya Wisesa Tbk PT in 2018 which means that it has the highest Size level of $299.27 \%$ during the period of this study. The average value generated from the 46 samples studied, the average company has a level of company size of Rp. 26.784804 or $267.85 \%$ with a standard deviation of 3.123322 greater than 1 , which means that the data distribution is heterogeneous.

4. In the Return on Asset (ROA) variable, the descriptive statistical results show the drinking value of Return on Assets (ROA) of 0.0000 owned by Fortune Indonesia Tbk PT in 2017 which means that the company has the most Return on Assets (ROA) level low is $0 \%$, while the maximum value of 0.3330 is owned by Surya Citra Media Tbk PT. in 2015 which means the company has the highest ROA level of $31.9 \%$. The average value generated from the 46 samples studied, the average company has a Return on Assets (ROA) level of 0.089261 or $8.92 \%$ with a standard deviation of 0.0818175 or $8.18 \%$ smaller than 1 , which means that the data dissemination is homogeneous.

5. In the Debt to Equity Ratio (DER) variable, the descriptive statistical results show a minimum value of 0.1870 owned by Fortune Indonesia Tbk PT in 2018 which means the company has the lowest Debt to Equity Ratio (DER) level of 1, 87\%. While the maximum value of 15.6460 owned by Jasuindo Tiga Perkasa Tbk PT in 2015 which means the company has the highest level of Debt to Equity Ratio (DER) is $15.64 \%$. The average value generated from the 46 samples studied, the average company has a level of Debt to Equity Ratio (DER) is 3.586500 or $358.65 \%$ with a standard deviation of 3.7807461 or $378.07 \%$ greater than 1 , which means that the data distribution is heterogeneous.

VI.A.1.2. Classic assumption test

To ensure that the estimated model meets the regression assumptions it can be done with a classic assumption test which includes:

a. Normality test

This study uses the Kolmogorov-Smirnov test to test the normality of normally distributed data or not with SPSS Decision making to determine whether or not the data is normally distributed is as follows:

- Asymp Value. Sig (2-tailed) $>0.05$ then it is normally distributed.

- Asymp Value. Sig (2-tailed) $<0.05$ then the data is not normally distributed.

One-Sample Kolmogorov-Smirnov Test

\begin{tabular}{|ll|r|}
\hline & & \multicolumn{1}{|c|}{ Unstandardized Residual } \\
\hline Normal Parameters & & 46 \\
& Mean &, 0000000 \\
& Std. Deviation &, 08550505 \\
Most Extreme Differences & Absolute &, 083 \\
& Positive &, 057 \\
Kolmogorov-Smirnov Z & Negative &,- 083 \\
Asymp. Sig. (2-tailed) & &, 563 \\
\hline
\end{tabular}

a. Test distribution is Normal. 
b. Calculated from data.

The Kolmogorov-Smirnof One-Sample test results in table 4.2 show the Kolmogorov-Smirnof value of 0.563 and a significant probability level of 0.910 . Because the $\mathrm{P}$ value (Asymp.Sig) is greater than the 5\% significance level, it can be concluded that the residual data in this regression model are normally distributed. In other words, the regression model used meets the assumption of normality.

b. Multiculturality Test

To find out the correlation between variables by looking at the value of tolerance and VIF. In order to avoid correlation, the value that must be met is tolerance value $>0.10$ and VIF value $<10$. To know whether there is multicollinity in the regression model can be seen from the picture as follows:

Coefficients

\begin{tabular}{|c|c|c|c|c|c|c|c|}
\hline \multirow[t]{2}{*}{ Model } & \multicolumn{2}{|c|}{ Unstandardized Coefficients } & \multirow{2}{*}{\begin{tabular}{|c|} 
Standardized Coefficients \\
Beta
\end{tabular}} & \multirow[t]{2}{*}{$\mathrm{t}$} & \multirow[t]{2}{*}{ Sig. } & \multicolumn{2}{|c|}{ Collinearity Statistics } \\
\hline & B & Std. Error & & & & Tolerance & VIF \\
\hline (Constant) &,- 353 & , 127 & & $-2,772$ & 008 & & \\
\hline SIZE &, 017 &, 005 & ,47 & 3,783 & 000 & 837 & 1,195 \\
\hline${ }^{1}$ ROA &, 815 &, 170 & ,58 & 4,783 &, 000 & ,896 & 1,116 \\
\hline DER &, 005 &, 004 & , 15 & 1,271 &, 211 & 929 & 1,077 \\
\hline
\end{tabular}

a. Dependent Variable: ETR

The multicollinearity test results presented in Table 4.3 above show that all variables have a tolerance value of more than 0.10 and a VIF value of less than 10 . Then it can be concluded that there is no multicollinearity between variables in this regression model.

b. Autocorrelation Test

Autocorrelation test is used to test whether there is a correlation between the error of the intruder in period $t$ and the error of the intruder in periodet-1 (before) in the regression model (Ghozali, 2013). In this study will use a run test where the criteria for determining whether autocorrelation symptoms have occurred or not, can be seen from if the Asymp value. Sig. (2-tailed) is greater than 0.05 then there are no symptoms of autocorrelation, so the autocorrelation test is fulfilled.

\section{Runs Test}

\begin{tabular}{|l|r|}
\hline & Unstandardized Residual \\
\hline Test Value &, 00797 \\
Cases $<$ Test Value & 23 \\
Cases $>=$ Test Value & 23 \\
Total Cases & 46 \\
Number of Runs & 17 \\
Z & $-1,938$ \\
Asymp. Sig. (2-tailed) &, 053 \\
\hline
\end{tabular}

a. Median

Based on the table above, there is Asymp. Sig. (2-tailed) is 0.053 or greater than 0.05 which means there is no autocorrelation and passes the autocorrelation test to be continued.

c. Heteroscedasticity Test

If the variance from one observation residual to another observation is fixed, then it is called Homoscedasticity and if different is called heteroscedasticity. One method used to detect heteroscedasticity is the Scatterplot. Scatterplot seen from the spread of the points in the picture. Based on the results of data processing with the help of SPSS, the values of the sactterplot images are as follows: 


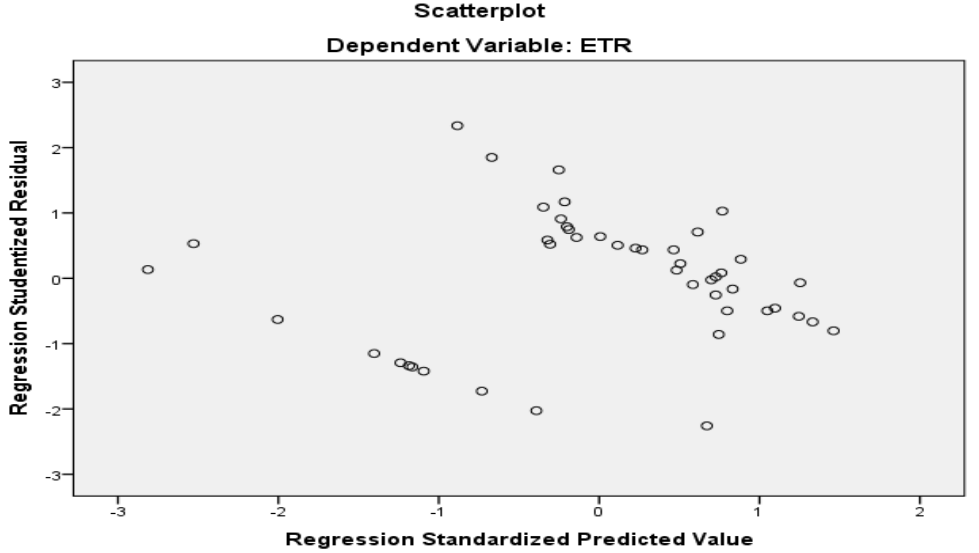

Based on the picture above, the results obtained Heteroscedasticity test results in the form of points or scatterplots spread above and below the number 0 on the $\mathrm{Y}$ axis, which means that there is no heteroscedasticity. VI.A.1.3. Model Conformity Test

a. Determination Coefficient Test $\left(\mathrm{R}^{2}\right)$

The coefficient of determination (R2) is intended to measure the extent to which the ability of the model or independent variables together affect the variation of the dependent variable. The coefficient of determination (R2) in the regression model between 0 and 1 , where the value of $\mathrm{R} 2$ is small or close to 0 means the ability of independent variables in explaining the variation of the dependent variable is very limited, on the contrary, if R2 is getting closer to $100 \%$ means all the independent variables in the mold provide almost all the information needed to predict the dependent variable or the greater the effect of all the independent variables on the dependent variable, Erwian AP; Dyah R.S (2011: 195).

Table 4.5

Model Summary ${ }^{b}$

\begin{tabular}{|c|c|c|c|c|}
\hline Model & $\mathrm{R}$ & R Square & Adjusted R Square & Std. Error of the Estimate \\
\hline 1 &, $662^{\mathrm{a}}$ & 439 & 399 & 0885061 \\
\hline
\end{tabular}

a. Predictors: (Constant), DER, ROA, SIZE

b. Dependent Variable: ETR

Based on the table above, it can be seen that the R Square coefficient is 0.439 or $43.9 \%$ with the Adjusted R Square value of 0.399 or $39.9 \%$. This means that $43.9 \%$ can be explained or influenced by the three Independent Variables namely Company Size (SiZE), ROA, DER on Tax Aggressiveness, while the remaining 59.1\% (100\% $-43.9 \%$ ) is explained or influenced by variables others not examined.

b. Simultaneous Significant Test (F-Test Test)

Statistical Test $\mathrm{F}$ is a significance test jointly of all independent variables on Dependent Variables with the observed regression line. With a level of confidence (5\%), the decisions made are:

- If the significant level $\mathrm{F}<0.05$ and $\mathrm{F}$ arithmetic $>$ from the $\mathrm{F}$ table, it can be concluded that all independent variables simultaneously or simultaneously affect the dependent variable.

- If the significant level $\mathrm{F}>0.05$ and $\mathrm{F}$ arithmetic $<$ from $\mathrm{F}$ table then it can be concluded that all independent variables simultaneously or simultaneously do not affect the dependent variable.

Table 4.6

ANOVA ${ }^{\mathrm{a}}$

\begin{tabular}{|ll|r|r|r|r|r|}
\hline Model & & \multicolumn{1}{|c|}{ Sum of Squares } & df & \multicolumn{1}{|c|}{ Mean Square } & \multicolumn{1}{c|}{ F } & Sig. \\
\hline \multirow{2}{*}{1} & Regression &, 257 & 3 &, 086 & 10,949 &, $000^{\mathrm{b}}$ \\
& Residual &, 329 & 42 &, 008 & & \\
& Total &, 586 & 45 & & & \\
\hline
\end{tabular}

a. Dependent Variable: ETR

b. Predictors: (Constant), DER, ROA, SIZE

Based on the results of the table above, it can be seen that the simultaneous test value ( $\mathrm{F}$ test is 10.949 with a sign value of 0.000 . While the $F$ table's value at the 0.05 significance level of 2.83 is obtained from $\mathrm{dfl}=\mathrm{k}-1$ where $\mathrm{k}$ is the number of variables examined $(4-1=3)$ and $\mathrm{df} 2=\mathrm{n}-\mathrm{k}$ where $\mathrm{n}$ is the number of samples ( $46-4=42$ ). Because the $F$ count is $10.949>$ from the $F$ table 2.83 with a significance of $0.001<0.05$, it can be concluded that all independent variables namely Company Size, Profitability and Leverage Ratios have a 
significant effect on the dependent variable, namely Tax Aggressiveness.

VI.A.1.4. Hypothesis Test

a. Significance Test of Individual Parameters (T-Test)

b. Acceptance or rejection of the hypothesis is carried out with the following criteria:

c. - If the significance value of $\mathrm{t}<0.05$ then $\mathrm{H} 0$ is rejected, it means that there is a significant influence between one independent variable on the dependent variable.

- If the significance value of $\mathrm{t}>0.05$ then $\mathrm{H} 0$ is accepted, it means that there is no significant effect between one independent variable and the dependent variable.

Table 4.7

Coefficients $^{\mathrm{a}}$

\begin{tabular}{|l|r|r|r|r|r|}
\hline \multirow{2}{*}{ Model } & \multicolumn{2}{|c|}{ Unstandardized Coefficients } & Standardized Coefficients & \multirow{2}{*}{$\mathrm{t}$} & \multirow{2}{*}{ Sig. } \\
\cline { 2 - 5 } & \multicolumn{1}{|c|}{ B } & Std. Error & Beta & & \\
\hline \multirow{2}{*}{ (Constant) } &,- 353 &, 127 & $-2,772$ &, 008 \\
SIZE &, 017 &, 005 &, 478 & 3,783 &, 000 \\
ROA &, 815 &, 170 &, 584 & 4,783 &, 000 \\
DER &, 005 &, 004 &, 152 & 1,271 &, 211 \\
\hline
\end{tabular}

a. Dependent Variable: ETR

Based on table 4.10 of the results of the t test summary, the following conclusions can be concluded:

a. Company Size Variable (SIZE) of T count 3.783 $>$ from T table 2.018 with a significance value of $0.000<$ than the probability value of 0.05 . This shows that the Company Size variable (SIZE) has a positive effect on tax aggressiveness or the first hypothesis is accepted.

b. Profitability variable (ROA) $\mathrm{T}$ value is $4.783>$ than $\mathrm{T}$ table 2.018 with a significance value of $0.000<$ than the probability value of 0.05 . This shows that the profitability variable (ROA) has a significant positive effect on tax aggressiveness, so the second hypothesis is accepted.

c. The Leverage variable (DER) has a T value of $1.277<$ than the T table of 2.018 with a significance value of $0.211>$ than a probability value of 0.05 . This shows that the Leverage (DER) variable does not affect the Tax Aggressiveness, so the third hypothesis is rejected.

b. Multiple Linear Regression Test

This study uses multiple regression to describe the relationship of several variables, so that a variable can be predicted from other variables. The form of the equation in this study is:

$\mathrm{Y}=-0,353+0,017 \mathrm{X} 1+0,815 \mathrm{X} 2+0,005 \mathrm{X} 3+\mathrm{e}$

From the results of the regression it can be concluded that:

1.Constants $\alpha=$ constants are $-0,353$. This shows that without the influence of the independent variable Company Size, Profitability and Leverage, the variable value of the Tax Aggressiveness Dependent remains constant at -0.353 . This negative constant value indicates a negative effect on the independent variable.

2. Regression coefficient value of the company size of 0.017 means that every time there is an increase in reporting of company size of $1 \%$, it will be followed by an increase in tax aggressiveness of $1.7 \%$ with the assumption that the other independent variables remain constant or constant.

3. The value of the regression coefficient of the Profitability variable (ROA) of 0.815 means that each increase in reporting profitability of $1 \%$ will be followed by an increase in Tax Aggressiveness of $8.15 \%$ with the assumption that the other independent variables remain constant or constant and show a positive relationship between Tax aggressiveness. The calculation assumes that other variables do not increase or decrease.

4. Leverage variable regression coefficient (DER) of 0.005 means that every time there is an increase in reporting Leverage (DER) of $1 \%$, it will be followed by an increase in tax aggressiveness of 0.005 with the assumption that the other independent variables remain constant or constant. From these results it shows a negative relationship between leverage and tax aggressiveness. This calculation is assumed that other variables do not increase or decrease.

\section{DISCUSSION}

Effect of Company Size on Tax Aggressiveness (H1).

Based on the $t$ test of the Company Size Variable (SIZE) of T count $3.783>$ of the $T$ table 2.018 with a significance value of $0,000<$ than the probability value of 0.05 . This shows Ha1 is accepted and Hol is dot, meaning that the Company Size variable (SIZE) has a positive effect on tax aggressiveness.

Company size, which is a measurement that companies can classify into small and large according to various ways such as total assets or total assets of the company, the average level of sales of stock market value, and total sales, 
(Machfoedy (1994) quoted by Findria P (2017). The classification of companies can be divided into large, medium and small companies Based on accounting standards classified as Micro, Small, Medium and Large Enitas, the larger size of the company certainly has more complex management behavior in the management of company operations, large scale companies certainly have more experience long time to carry out its operations, and have more experience in strategies for operational sustainability, including tax minimization (Kristanto, 2013). Company Size (Size) is a scale where companies can be classified in terms of size and size, one of them is the size assets yes ng owned (Ardyansah, zulaikha, 2014: 3). The results of this study are in accordance with previous studies such as A.W Laksono; S.s Albertus; R.Vhalery; (2019) Firm size, profitability have a negative effect on tax aggressiveness and company size and profitability have an effect on tax aggression. Also with Vita Avianti Lusiana's research (2017 which mentions that company size has a negative and not significant effect on tax aggressiveness, and corporate social responsibility and leverage has a negative and significant effect on tax aggressiveness.

But this study is not in line with previous studies such as Findria P's research (2017) states, Company Size has no effect on tax aggressiveness. Dewi Nawang Gemilang (2017), said company size had no significant effect on corporate tax aggressiveness. According to Giawan Research; Riaty (2019) Company size has no effect on tax avoidance.

Effect of Profitability Ratio (ROA) on Tax Aggressiveness (H2) Based on the t test the profitability variable (ROA) $\mathrm{T}$ value was $4.783>$ than the $\mathrm{T}$ table 2.018 with a significance value of $0.000<$ than the probability value of 0.05 . This shows that the profitability variable (ROA) shows that Ha2 is accepted and Ho2 is rejected which can mean that partially the profitability ratio (ROA) has a significant effect on tax aggressiveness. Profitability is a value or benchmark that is often seen by investors to assess company performance. According to G. Sugiyarso and F. Winarni (2005: 118) profitability is the ability of companies to earn profits in relation to the sale of total assets and own capital. From this definition it is clear that the target to be sought is the company's profit. Profitability of a company shows the ratio between earnings with assets or capital that generates profits. In other words, profitability is the ability of a company to achieve profits. The results of this study are in accordance with previous studies such as that of Putu Ayu Seri Andhari and I Made Sukartha (2017), stating that profitability has a positive effect on tax aggressiveness the more a company earns profit, the more aggressive the company also practices avoidance of its tax obligations. But the results of this study contradict the previous research, Agus Taupik Hidayat1, Eta Febrina Fitria2 (2018), Profitability has no effect on tax aggressiveness, companies, the same as the research results of Adeherdian Permata Putri (2019), Return on Assets (ROA) has no effect significant to tax aggression. Effect of Leverage Ratio (DER) on Tax Aggressiveness (H3). Based on the t test Variable Leverage (DER) has a calculated $\mathrm{T}$ value of $1.277<$ than the 2.018 table with a significance value of $0.211>$ than the probability value of 0.05 . This shows that the Leverage variable (DER) indicates that Ha3 is rejected and Ho2 is accepted which can mean that partially the leverage ratio has no significant effect on tax aggressiveness. The leverage ratio using Debt Equity Ratio (DER) is one of the ratios to measure the level of leverage

Solvency Ratios or Leverage Ratios are ratios used to measure the extent to which company assets are financed with debt. In broad terms, the solvency / leverage ratio is used to measure the company's ability to meet all its obligations both short-term and long-term obligations (Hery. 2015). Leverage is the use of assets and sources of funds by companies that have fixed costs (fixed costs) with a view to increasing potential shareholder returns (Sartono, 2008: 257). Leverage is a level of a company's ability to use assets and / or funds that have a fixed burden (debt and or special stock) in order to realize the company's goals to maximize the owner's wealth. The results of this study are consistent with previous studies such as in Andy Research (2018), mentioning Debt to Equity Ratio (DER) has no significant effect on tax avoidance, whereas simultaneously Debt to Equity Ratio (DER) has a significant effect on tax avoidance. But the results of this study contradict with research In the study of Imam Fadli (2016) states leverage affects the corporate tax aggressiveness.

\section{CONCLUSIONS}

Based on the results of the analysis and discussion carried out, it is concluded:

1. Company Size

The company size variable has a significant effect on tax aggressiveness. The greater the size that is proxyed for total sales, the greater the profit earned and this will have an impact on the tax burden that is even greater. Considering that the company wants to get more profit, it is likely that the company will be able to carry out tax aggressiveness both through tax avoidance and tax avasion.

2. Profitability Ratio (ROA)

The profitability ratio variable which is proxied by Return on Assets (ROA) has a positive effect on tax aggressiveness, which means the higher the level of profitability of the company, the level of action to carry out greater tax aggressiveness

3.Leverage Ratio (DER).

Leverage ratio variable (DER) does not have a positive effect on tax aggressiveness, because with the higher level 
of leverage, the interest costs incurred by the company as a deduction of profit will be greater and will have an impact on reducing the tax burden, so that without tax aggressive action, tax burden paid

\section{Bibliography}

Agus Taufik Hidayat1, Eta Febriana Fitria2, (2018) Pengaruh Capital Intensity, Inventory Intensity, Profitabilitas dan leverage terhadap Agresivitas Pajak, STIE PGRI Dwantara Jombang. ISSN 2549-6018(online) ISSN 19-07-7513(Print)

Alfiyani Nur Hidayanti. 2013. Pengaruh antara Kepemilikan Keluarga dan Corporate Governance Terhadap Tindakan Pajak Agresif. E-Jurnal Akuntansi Jurusan Ekonomi, Universitas Diponegoro, Semarang.

Andhari, Putu Ayu Seri. I Made Sukartha, 2017. E-Jurnal Akuntansi Universitas Udayana Vol.18.3. Maret (2017): 2115-2142

Ardiansyah, Muhammad. 2014. Pengaruh Corporate Governance, Leverage Dan Profitabilitas Terhadap Manajemen Laba. Jurnal Akuntansi, Universitas Maritim Raja Ali Haji.

Adeherdian Permata Putri (2019), Pengaruh Likuiditas, leverage, Return On Asset (ROA), capital intensity dan inventory Intensity terhadap Agresivitas Pajak, Universitas Islam negeri Sultan Syarif Kasim, Riau.

Adisamartha, I.B.P.F., dan Noviari, N. 2015. Pengaruh Likuiditas, Leverage, Intensitas Persediaan Dan Intensitas Aset Tetap Pada Tingkat Agresivitas Wajib Pajak Badan. E-Jurnal akuntansi universitas udayana, Vol 13, No.3, Desember 2015, hal 977-978, 980, 994-995

Andy (2018), Pengaruh Return On Aset, Debt to Equity Ratio, ebt to asset Ratio, Ukuran Perusahaan dan Derred tax Expense terhadap Tax Avoidance. Vol.16 No.2(2018)

A.W Laksono; S.S Albertus; R.Vhalery (2019), Pengaruh Ukuran perusahaan dan profitailitas terhadap agresivitas Pajak pada perusahaan Manufaktur yang listing di BEI periode 2013-2017. Journal of applied business and economic vol.5.no.4 (Juni 219 301-314)

Bey, F. Firami. (2016) Pengaruh Corporate Governance Dan Corporate Social Responsibility Terhadap Agresivitas Pajak. Jakarta : Pascasarjana Universitas Mercu Buana.

Cahya A. K \& Amrie Firmansyah, 2018. Jurnal Tekun. Vol. 8. No. 1. Maret 2018.

Chen, S., X. Chen, Q. Cheng, dan T. Shevlin. 2010. Are Family Firms More Tax Aggressive Than Non-family Firms?. Journal of Financial Economics, 95, $h:$ 41-61.

Dendawijaya, Lukman. 2003. Manajemen Perbankan. Jakarta: Ghalia Indonesia.

Desai, M., \& D. Dharmapala. 2006. Corporate Tax Avoidance and Firm Value. Working Paper Harvard University.

Etty, M.Nasset dan E.Rasita. 2005, Pemilihan Metode Akuntansi persediaan berdasarkan ricardian Hypotesis, teory Agency dan Political Cost, Jurnal Ekonomi. No.4/TH.XIV.

Erwan A.P; Dyah R.S (2011;37) Metode Penelitian Kuantitatif, untuk administrasi Pubik dan masalah-masalah sosial. Edisi Pertama, cetakan kedua, ISBN: 979-1078-11-4

Fadli, Imam. 2016. Pengaruh Likuiditas, Komisaris Independen, Manajemen Laba, dan Kepemilikan Institusional Terhadap Agresivitas Pajak Perusahaan. JOM Fekom. Vol. 3, No. 1.

Fahmi, Irham. (2011). Analisa Laporan Keuangan. Bandung : Alfabeta.

Fikriyah, 2013. Analisis Pengaruh Likuiditas, Leverage, Profitabilitas, dan Karakteristik Kepemilikan terhadap Agresivitas Pajak Perusahaan (Studi pada perusahaan sektor pertambangan yang terdaftar di BEI Tahun 2010-2012). Malang.

Findria Prameswari (20117), Pengaruh Ukuran perusahaan terhadap agresivitas pajak dengan Corporate Social Responsibility (CSR) sebagi Vvariabel Moderasi. Jurnal ekonomi Akuntansi Vol.3 Issue 4(2017).

Gemilang, Dewi Nawang. 2017. "Pengaruh Likuiditas, Leverage, Profitabilitas, Ukuran Perusahaan dan Capital Intensity terhadap Agresivitas Pajak Perusahaan" dalam Skripsi. Surakarta : Fakultas Ekonomi dan Bisnis Islam IAIN Surakarta.

Ghozali, Imam. 2013. Aplikasi Analisis Multivariate dengan Program IBM SPSS 21 Update PLS Regresi. Semarang: Badan Penerbit Universitas Diponegoro.

Giawan Nur Fitria (2018), Pengaruh Kepemilikan Institusional, komisaris Independen, karakter eksekutif dan size terhadap Tax Avoidance, (Study Empiris Pada Emiten Sektor Perdagangan yang Terdaftar di BEI Tahun 2014-2017, Profita: ISSN: 2086-7662 Vol. 11 No. 3 Desember 2018 e-ISSN: 2622-1950

Giawan N.F; Riaty H; (2019, Tax Avoidance: Studi Empiris pada Perusahaan masunaktor barang konsumsi di Indonesia (Jurnal Monex Vol.8 No.1, p-ISSN:2089-6778; e-ISSN:2549-5054

Hery. 2015. Analisis Kinerja Manejemen. Kompas Gramedia. PT. Grasindo, Jakarta (2014).

Hanafi, Mamduh M. dan Abdul Halim, 2014, Analisis Laporan Keuangan., Edisi tujuh., UPP AMP YKPN, Yogyakarta.

Hanafi. 2004. Manajemen Keuangan. Yogyakarta: BPFE UGM.

Harahap, Rosna K., dan D.M.Jiwana. (2009). Analisis faktor-faktor yang berpengaruh terhadap pemilihan metode akuntansi persediaan pada perusahaan manufaktur di Bursa Efek Jakarta. Media Riset Akuntansi,Auditing dan Informasi. No.3/TH.2009.

Ikatan Akuntan Indonesia (IAI). (2009). Pernyataan Standar Akuntansi Keuangan (PSAK) No. 46: Akuntansi Pajak Penghasilan. Jakarta: Salemba Empat.

Irawati, Susan. 2006. Manajemen Keuangan. Bandung: Pustaka.

Jensen, Michael C. dan Meckling. William H., 1976, "Thery of The Firm: Managerial Behavior, Agency Cost, and Ownership Structure", Jurnal of Financial Economics, Vol. 3, No. 4, October pp. 305-360.

Kasmir. (2012), Analisis Laporan Keuangan. Jakarta : PT. Raja Grafindo Persada

Lestari, Maharani Ika., Sugiharto, Toto. 2007. Kinerja Bank Devisa dan Bank Non Devisa dan Faktor - Faktor yang Mempengaruhinya. Proceeding PESAT (Psikologi, Ekonomi, Sastra, Arsitek \& Sipil). 21-22 Agustus, Vol 2. Fakultas Ekonomi, Universitas Gunadarma.

Liu, X and S. Cao. 2007. Determinants of Corporate Effective Tax Rates. The Chinese Economy, 40 (6), 49-67.

Nengzih (2019. The Influence of Corporate Governance, Tax Avoidance, Leverage, and Company Size to Earnings 
Management: Empirical Study from Indonesia's Banking Companies 2015-2017. Scholars Bulletin, Vol. 5, ISSUE .1; ISSN: 2412-9771

Maharani, I Gusti Ayu Cahya dan Ketut Alit Suardana. 2014. Pengaruh Corporate Governance, Profitabilitas, dan Karakteristik Eksekutif Tax Avoidance Perusahaan Manufaktur. E-Jurnal Akuntansi Universitas Udayana ISSN: 2302-8556.

Maharani, I Gusti Ayu Cahya dan Ketut Alit Suardana. 2014. Pengaruh Corporate Governance, Profitabilitas, dan Karakteristik Eksekutif Tax Avoidance Perusahaan Manufaktur. E-Jurnal Akuntansi Universitas Udayana ISSN: 2302-8556.

Miza Ariani, Mhd.Hasyim (2018), Pengaruh Profitabilitas, likuiditas, leverage, size, dan capilta intensity ratio terhadap effecctive tax rate (ETR). Jurnal Profita Komunikasi ilmiah Akuntansi dan Perpajakan Vol.11 No.3 P-ISSN:2086-7662; e-SSN:2622-1950)

Munawir, S. 2010. Analisis laporan Keuangan Edisi keempat. Cetakan Kelima Belas. Yogyakarta: Liberty

Nugraha, Novia Bani dan Wahyu Meiranto. 2016. Pengaruh Corporate Social Responsibility, Ukuran Perusahaan, Profitabilitas, Leverage, dan Capital Intensity Terhadap Agresivitas Pajak. Jurnal Universitas Diponegoro. Vol. 4. No. 4.

Nur Amalia Sari.2018, Pengaruh Profitabilitas, dan Leverage terhadap Penghindaran Pajak dengan Pengungkapan Corporate Social Responsibility sebagai variabel Demoderasi.

Peraturan Bapepam dan LK tahun 2012 No. X.K.6. Peraturan Menteri Keuangan Republik Indonesia Nomor 43/PMK.03/2008 (DJP-2008).

Prakosa, K. B. 2014. Pengaruh Profitabilitas, Kepemilikan Keluarga, dan Corporate Governance terhadap Penghindaran Pajak di Indonesia. Simposium Nasional Akuntansi XVII. 24-27 September 2014, Lombok.

Prasista, Putu Meita, Ery Setiawan, 2016. E-Jurnal Akuntansi Universitas Udayana Vol.17.3. Desember (2016): 2120-2144.

Republik Indonesia, Undang-Undang No. 28 Tahun 2007, "Ketentuan Umum dan Tata Cara Perpajakan"

Resmi, Siti. 2017. Perpajakan: Teori dan Kasus. Jakarta: Salemba Empat.

Richardson, Grant dan Roman Lanis. 2007. Determinants of the Variability in Corporate effective Tax Rates and Tax Reform:Evidence from Australia. Journal of Accounting and Public Policy. 26 (2007) 689-704.

Riyanto, B. (2001). Dasar-dasar Pembelanjaan Perusahaan, edisi 4. Yogyakarta: BPFE-Yogyakarta.

Riaty Handayani (2019, Analisis Tanggung Jawab Sosial perusahaan dan tata Kelola Perusahaan yang baik terhadap Agresivitas Pajak. Universitas Mercu Buana. ISSN:2225-8329, P-ISSN: 2308-0337

Sari, D. Martani. (2010). Karakteristik Kepemilikian Perusahaan, Corporate Governance, dan Tindakan Pajak Agresif. Tesis program studi magister akuntansi Fakultas Ekonomi Universitas Indonesia. Depok.

Sartono, Agus. 2008. Manajemen Keuangan Teori, dan Aplikasi. Yogyakarta: BPFE Yogyakarta.

Sjahrial, Dermawan, 2009. Manajemen Keuangan. Edisi Tiga. Jakarta: Mitra Wacana Media.

Sugiyarso, G.Winarni, F. (2005). Manajemen Keuangan. Media Pressindo, Yogyakarta.

Sumarsan, Thomas. 2013. Perpajakan Indonesia Edisi 3, Jakarta: Penerbit Indeks.

Tarmidi, D. (2019). Tax Compliance and Uncompliance Entity: A Comparative Study of Investor Reaction, International Journal of Academic Research in Accounting, Finance and Management Sciences 9(1): 105-110, E-ISSN: 22258329, P-ISSN: 2308-0337

Tiffani Damayanti, Masfar Gazali (2018. Pengaruh Capital Intensity Ratio, dan Inventory Intensity terhadap Effective Tax Ratio. ISSN (P): 2460-8696, ISSN (E): 2540-7589.

Vita Avianti Lusiana (2017), Pengaruh Corporate Social Responsibility,ukuran Perusahaan Dan Leverage Terhadap Agresivitas Pajak. FEB Usakti, Jakarta (2017)

Waluyo. 2017. Perpajakan Indonesia. Jakarta: Salemba Empat

Yulfaida dan Zulaikha. 2012. Pengaruh size, profitabilitas, profile, leverage dan ukuran dewan komisaris terhadap pengungkapan tanggung jawab sosial pada perusahaan manufaktur di Bursa Efek Indonesia. Semarang: UNDIP, Diponegoro journal of accounting. Vol 1, No. 2, 1-12.

Zeng, T. (2012). “Corporate Social Responsibility and Tax Aggressiveness”. Social Science Research Network.

https://www.finansialku.com/tax-ratio/

http://kontan.co.id/2014

www.kemenperin.go.id

www.ortax.org.id 